\title{
INVESTIGASI DAN REKAYASA TAPAK REKLAMASI: STATE OF ART SUATU SOLUSI UNTUK MENUNJANG PASCATAMBANG TIMAH ALLUVIAL YANG BERKELANJUTAN
}

\author{
1)Budi Sulistijo", 2)Chusharini Chamid dan ${ }^{3) A d r i y a n t o ~ D ~ K u s u m o ~}$ \\ ${ }^{1}$ Kelompok Keahlian Esplorasi Sumberdaya Bumi, Fakultas Teknik Pertambangan dan Perminyakan,ITB \\ ${ }^{2}$ Fakultas Teknik, Universitas Islam Bandung \\ ${ }^{3} P T$ Solusi Global Berkelanjutan
}

Artikel masuk : 26-03-2021, Artikel diterima : 31-03-2021

\author{
Kata kunci: \\ Reklamasi, timah aluvial,Drone \\ Keywords: \\ Reclamation,Alluvial Tin,Drone
}

*Corresponding author: budis@mining.itb.ac.id

Doi : https://doi.org/10.36986/impj.v2i2.36

\begin{abstract}
ABSTRAK
Reklamasi pada area bekas tambang merupakan salah satu tantangan untuk merepresentasikan wujud nyata manajemen berkelanjutan pada sektor pertambangan Indonesia. Kerangka kerja peraturan reklamasi dan pasca tambang di Indonesia menetapkan berbagai persyaratan untuk melaksanakan kegiatan reklamasi dan pasca tambang. Sebagai langkah awal, para pemangku kepentingan diwajibkan untuk berkonsultasi secara detail tentang peraturanperaturan yang berlaku. Reklamasi timah alluvial (dan kemungkinan endapan logam alluvial lainnya) merupakan masalah yang pelik dalam mewujudkan program reklamasi pasca tambang yang berkelanjutan. Sering kali program reklamasi gagal karena adanya proses penambangan kembali di lahan yang sudah direklamasi. Masalah utama dalam proses reklamasi timah alluvial adalah bahaya geologi, hidrologi, hidrogeologi dan penambangan kembali. Dengan adanya datadata yang baik maka akan dapat dilakukan rekayasa teknik yang baik untuk mewujudkan reklamasi yang berkelanjutan. Penerapan teknologi tepat guna untuk mengantisipasi bahaya geologi, hidrogeologi, hidrologi serta monitoringnya sehingga aspek yang akan mengurangi keberhasilan program reklamasi sudah dapat diantisipasi sejak awal sehingga program pencegahannya dapat dilakukan sejak dini. Proses sterilisasi yang baik dilakukan sejak awal proses penambangan ataupun dilakukan sebelum proses penutupan tambang agar proses reklamasi dapat berjalan secara berkelanjutan.
\end{abstract}




\section{ABSTRACT}

Reclamation in ex-mining areas is one of the challenges to represent a tangible form of sustainable management in the Indonesian mining sector. The regulatory framework for reclamation and post mining in Indonesia sets out various requirements for carrying out reclamation and post mining activities. As a first step, stakeholders are required to consult in detail about applicable regulations. Reclamation of alluvial tin (and possibly other alluvial metal deposits) is a complex issue in realizing a sustainable post-mining reclamation program. Often the reclamation programs fail because of the mining process on land that has been reclaimed. The main problems in the alluvial tin reclamation process are geological, hydrological, hydrogeological and re-mining hazards. With good data from, good engineering can be carried out to achieve sustainable reclamation. The application of appropriate technology to anticipate geological, hydrogeological, hydrological hazards and to monitor them so that all aspects that will reduce the success of the reclamation program can be anticipated from the start so that prevention programs can be carried out early on. The sterilization process either done from the beginning of the mining process or before the mine closure process so that the reclamation process can run in a sustainable manner.

\section{PENDAHULUAN}

Reklamasi pada area bekas tambang merupakan salah satu tantangan untuk merepresentasikan wujud nyata manajemen berkelanjutan pada sektor pertambangan di Indonesia. Kerangka kerja peraturan reklamasi dan pasca tambang di Indonesia menetapkan berbagai persyaratan untuk melaksanakan kegiatan reklamasi dan pasca tambang. Sebagai langkah awal, para pemangku kepentingan diwajibkan untuk berkonsultasi secara detail tentang peraturan-peraturan yang berlaku.

Tulisan ini didasarkan pada pembelajaran di proyek reklamasi percontohan Air Kundur 3 dengan fokus pada tingkat teknis dari proses reklamasi. Tulisan ini harus dilihat sebagai pelengkap dari inisiatif nasional dan internasional lainnya yang mendukung reklamasi berkelanjutan di Indonesia. Penelitian ini diilhami oleh diskusi dengan para pemangku kepentingan Indonesia dan juga oleh contoh yang diberikan oleh Metodologi Rehabilitasi Frugal yang dikembangkan untuk penambangan skala kecil di Mongolia (The Asia Foundation, 2016).

Bijih timah telah ditambang di provinsi Bangka Belitung selama lebih dari 300 tahun. Banyak daerah di provinsi ini menunjukkan kerusakan lingkungan yang parah akibat kegiatan penambangan sebelumnya. Ada harapan yang tinggi dimasyarakat lokal bahwa semua area ini harus dikonversi menjadi lahan produktif yang menciptakan manfaat ekonomi bagi masyarakat lokal dan menggantikan pendapatan yang hilang karena penghentian kegiatan penambangan timah. Namun, meskipun manfaat ekonomi bagi masyarakat sangat penting, kecil kemungkinan bahwa target ini dapat dengan mudah dicapai dalam jangka pendek dan dalam skala luas, kecuali tersedia jumlah anggaran yang tidak terbatas.

Minimal, reklamasi seharusnya mengembalikan lahan yang telah ditambang ke kondisi alamiah seperti sebelum kegiatan penambangan dimulai, atau mengubahnya menjadi keadaan yang bermanfaat secara ekonomi bagi masyarakat. Karena tingginya kandungan granit dalam tanah, maka kesuburan alamiah tanah di provinsi Bangka Belitung tidak terlalu tinggi. Lapisan top soil yang ada telah dibersihkan ketika memulai kegiatan penambangan dan dalam banyak kasus, tanah tersebut belum ditimbun dengan baik untuk pemanfaatan selanjutnya sehingga top soil tersebut telah hilang saat ini. Endapan limbah tambang dan tailing yang meluas menciptakan kondisi bermasalah untuk pertumbuhan tanaman, bahkan untuk tanaman penutup, yang memperkuat risiko erosi dan banjir.

Oleh karena itu, dengan asumsi bahwa hanya ada ketersediaan dana reklamasi yang terbatas, target jangka pendek untuk reklamasi dari banyak area bekas tambang di provinsi Bangka Belitung adalah fokus pada peningkatan kondisi tanah untuk pertumbuhan tanaman. Hal ini dapat dicapai dengan menerapkan masterplan yang melibatkan langkah-langkah pengendalian erosi sederhana dan penanaman tanaman penutup serta pohon, yang mengarah pada peningkatan secara progresif parameter kesuburan tanah (konten organik, tekstur dll.) dan pengembangan hutan. Ini adalah proses yang lambat yang mungkin membutuhkan waktu setidaknya 10-20 tahun untuk menunjukkan kemajuan yang signifikan. Selama periode ini, masyarakat lokal akan menerima sedikit manfaat ekonomi dari daerah yang terkena dampak. Karena itu mereka mungkin memerlukan bentuk dukungan lain sebagai bagian dari konsep sosialekonomi yang lebih besar yang juga mencakup pengembangan kapasitas masyarakat lokal.

Pengambilan timah selama penambangan dan pemrosesan selalu kurang dari $100 \%$ dibandingkan dengan jumlah timah yang ditemukan dalam bijih. Tingkat perolehan menggambarkan persentase timah yang tersisa dalam produk akhir (konsentrat bijh timah) sebelum peleburan dibandingkan dengan jumlah timah dalam bijih pada kondisi awal. Timah sisa penambangan dapat ditinggalkan di bawah permukaan (jika terdapat daerah-daerah tertentu tidak ditambang sama sekali), di dalam limbah tambang (jika tanah penutup dihilangkan) dan dalam tailing yang dihasilkan dari pemrosesan timah.

Pengetahuan tentang timah sisa penambangan mempunyai peranan penting karena reklamasi area 
penambangan timah di Provinsi Bangka Belitung sering terganggu oleh penambangan kembali di area reklamasi. Kegiatan penambangan kembali ini mendapat insentif dari kenaikan harga timah: Penambangan kembali menjadi menarik selama periode harga timah tinggi dan hanya bisa dihindari jika (1) daerah tersebut tidak lagi menampung sumber daya timah sisa penambangan yang signifikan dan (2) masyarakat lokal, yang mungkin terlibat dalam tambang rakyat, memahami bahwa sumber daya timah telah habis.

Pemahaman resiko kegiatan penambangan yang tidak terkendali memerlukan gambaran terjadinya timah sisa penambangan. Gambar-gambar berikut (Gambar 1 dan Gambar 2) dan Tabel 1 mengidentifikasi lokasi-lokasi ini berdasarkan genesa endapan timah aluvial darat dan proses penambangan dan pengolahan timah tersebut.

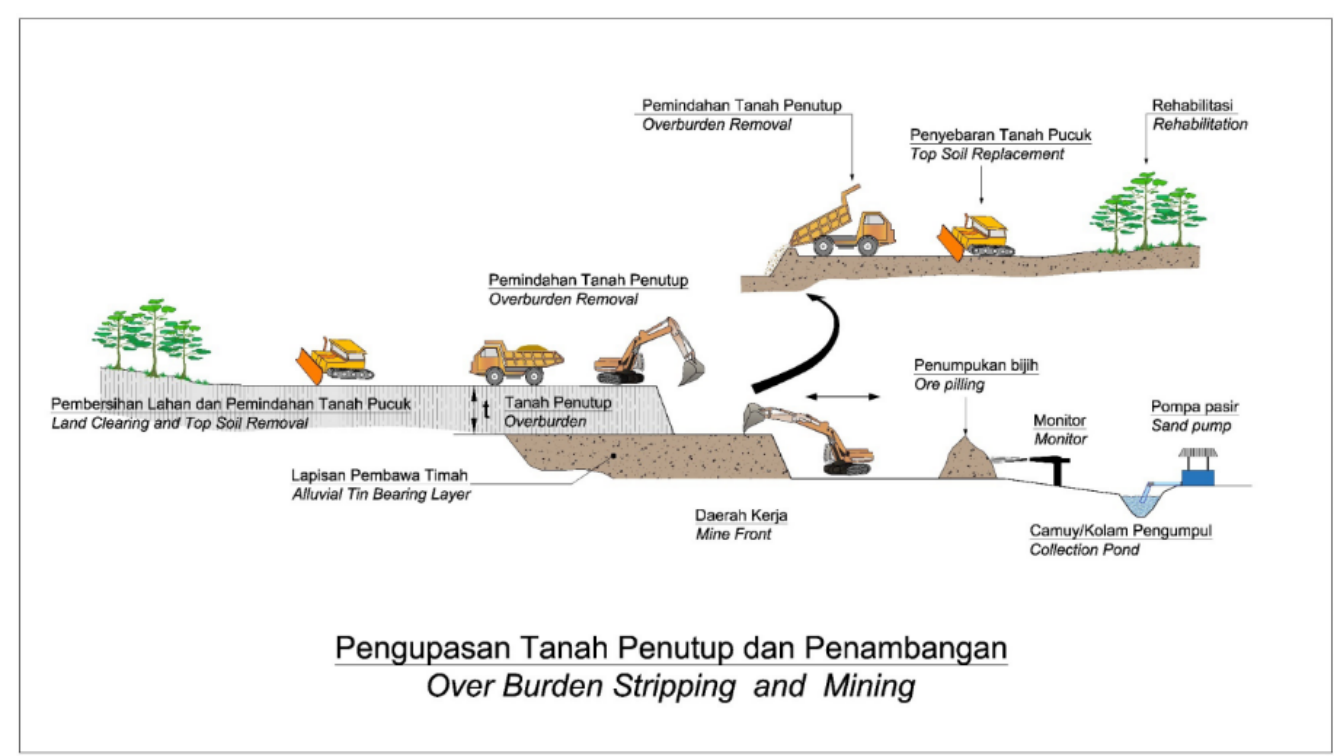

Gambar 1: llustrasi proses penambangan timah alluvial darat (Modifikasi dari Lubis, 2017)

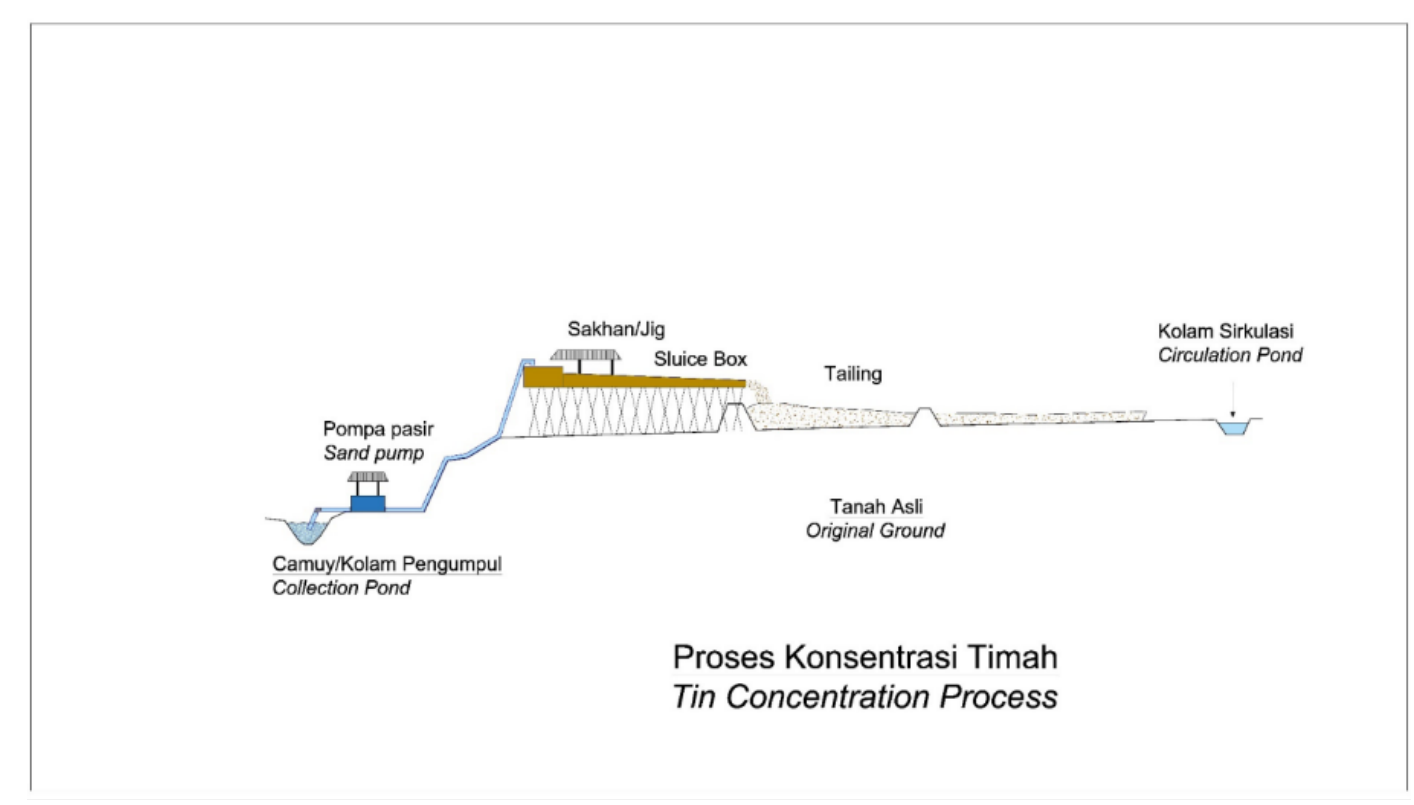

Gambar 2: llustrasi pengolahan/konsentrasi timah (Modifikasi dari Lubis,2017) 
Tabel 1: Kegiatan penambangan timah dan potensi hasil timah sisa penambangan

\begin{tabular}{|c|c|c|}
\hline No & Aktivitas penambangan & Potensi timah sisa penambangan \\
\hline 1 & $\begin{array}{l}\text { Pengupasan lapisan tanah pucuk untuk mendapatkan } \\
\text { lapisan penutup / lapisan pembawa timah, pembuangan } \\
\text { limbah penambangan, dan pembuangan limbah } \\
\text { pengolahan. Lapisan yang dikupas akan dikumpulkan di } \\
\text { lokasi penumpukan yang dekat dengan area tambang } \\
\text { untuk digunakan lebih lanjut. }\end{array}$ & $\begin{array}{l}\text { Kemungkinan timah masih ditemukan di area } \\
\text { timbunan lapisan tanah pucuk. }\end{array}$ \\
\hline 2 & $\begin{array}{l}\text { Pengupasan lapisan penutup, penggalian limbah batuan } \\
\text { pengangkutan dan pembuangan limbah berada di tempat } \\
\text { pembuangan limbah }\end{array}$ & $\begin{array}{l}\text { Kemungkinan bahwa timah masih ditemukan di } \\
\text { bagian atas daerah pembuangan. }\end{array}$ \\
\hline 3 & $\begin{array}{l}\text { Penggalian lapisan pembawa timah/kaksa, pengangkutan } \\
\text { dan penumpukan timah, dan pemberaian menggunakan } \\
\text { monitor. }\end{array}$ & $\begin{array}{l}\text { Jika bijh timah tidak diproses secara } \\
\text { sistematis dan masih terdapat di tambang yang } \\
\text { akan tutup maka daerah tersebut menjadi } \\
\text { target penambangan tanpa ijin. }\end{array}$ \\
\hline 4 & $\begin{array}{l}\text { Gaya gravitasi mengalirkan gravel dari pompa tambang } \\
\text { dan pengolahan (penumpukan bijih ke camuy/kolam } \\
\text { pengumpul). }\end{array}$ & $\begin{array}{l}\text { Area ini menjadi target intrusi penambang } \\
\text { tanpa ijin jika area tersebut tidak dibersihkan } \\
\text { dengan benar. }\end{array}$ \\
\hline \multirow[t]{2}{*}{5} & Tambahan pengolahan bijih dari camuy ke & $\begin{array}{l}\text { Lokasi penumpukan limbah pengolahan } \\
\text { menjadi target penambangan tanpa ijin jika }\end{array}$ \\
\hline & $\begin{array}{l}\text { Sluice box/sakhan/jig dan akhirnya konsentrasi dan } \\
\text { pembuangan limbah pengolahan. }\end{array}$ & $\begin{array}{l}\text { perolehan timah rendah. Kemungkinan kondisi } \\
\text { ini merupakan fenomena lokal - kadar bijih di } \\
\text { lokasi penumpukan limbah pengolahan dapat } \\
\text { heterogen. }\end{array}$ \\
\hline
\end{tabular}

\section{PENGUMPULAN DATA}

\section{Evaluasi Wilayah Reklamasi dan Kapasitas masyarakat}

Upaya perencanaan reklamasi dilakukan jauh sebelum memulai proses reklamasi yang sebenarnya. Idealnya, reklamasi zona bekas tambang harus dilaksanakan secara bertahap mengikuti kegiatan penambangan yang sedang berlangsung. Informasi latar belakang mengenai beberapa evaluasi dasar yang dapat membantu memastikan reklamasi yang hemat biaya dan berkelanjutan.

\section{Parameter Perencanaan dan Penilaian Risiko}

Sejumlah parameter dan risiko memengaruhi prospek keberhasilan reklamasi berkelanjutan di area tertentu. Evaluasi yang memadai atas parameter-parameter dan risiko-risiko ini dengan penyesuaian desain rencana reklamasi membutuhkan pengumpulan data dasar. Risiko dan parameter penting yang harus dievaluasi meliputi:

- $\quad$ Risiko penambangan ulang di wilayah bekas tambang yang telah direklamasi oleh penambang tanpa ijin karena masih adanya kandungan bijih timah yang tersisa.

- Risiko erosi yang mempengaruhi stabilitas tanah, dasar sungai, dan banjir.

- Ketersediaan air dengan kualitas yang memadai untuk mendukung proses reklamasi. Ini termasuk pertimbangan perencanaan jangka pendek untuk reklamasi yang optimal dalam siklus musim kering tahunan dan perkembangan iklim jangka panjang.

- Faktor sosial ekonomi dimana masyarakat lokal tidak dihargai atau tidak terlibat dalam proses reklamasi dan tidak ada model bisnis masyarakat jangka panjang. Ini lebih lanjut mencakup pertanyaan tentang kepemilikan tanah dan perencanaan penggunaan lahan setelah periode awal reklamasi dan pemeliharaan area.

\section{Pelibatan Masyarakat dalam Proses Reklamasi}

Masyarakat dapat memainkan peran positif dalam proses reklamasi dan juga dalam pemeliharaan kawasan tersebut atau dalam model bisnis pascatambang yang terkait. Jika mereka dapat dilibatkan sebagai pemangku kepentingan, investor atau pemilik tanah dari lahan bekas tambang, mereka dapat bertindak sebagai pendukung target reklamasi jangka panjang dan mengurangi risiko seperti penambangan kembali secara ilegal di area tersebut.

Situasi sosial ekonomi masyarakat lokal dan peran potensial mereka dalam mengembangkan konsep reklamasi dan pascatambang mungkin berbeda dari satu tempat ke tempat lain. Oleh karena itu, tidak ada pendekatan standar "satu ukuran untuk semua". Penting untuk memahami situasi individual komunitas 
lokal secara cukup rinci sebelum melaksanakan proyek reklamasi.

\section{Desain Area}

Untuk tujuan mengembangkan rencana reklamasi di area bekas tambang, perlu untuk memeriksa status lahan dan kondisi tutupan lahan, dan menyiapkan peta dasar area tersebut.

- Periksa status lahan bekas tambang dengan merujuk pada peta status lahan dan Rencana Tata Ruang Wilayah (RTRW). Apakah itu hutan atau Area untuk Penggunaan Lain (APL)? Peta-peta ini dapat diperoleh dari Kantor Bappelitbangda Provinsi dan Kabupaten.

- Dapatkan peta topografi pada skala yang dapat secara memadai menggambarkan kondisi mikro-topografi area tersebut. Petapeta ini mungkin tidak tersedia pada resolusi yang memadai; dalam hal itu, peta baru dapat dibuat, mis. menggunakan drone untuk membangun model lanskap tiga dimensi. Idealnya, garis kontur harus diselesaikan dengan perbedaan ketinggian 1 meter, sehingga mereka juga dapat menggambarkan kondisi tutupan lahan termasuk ukuran, kedalaman, dan distribusi kolong, ketinggian tumpukan lapisan penutup, dll.

Ukuran satu unit area reklamasi seringkali kurang dari $10 \mathrm{Ha}$. Peta topografi yang mencakup wilayah tersebut umumnya tersedia dalam skala 1: 50.000 yang tidak berguna untuk menginterpretasikan kondisi tutupan lahan dengan luas kurang dari $10 \mathrm{Ha}$. Oleh karena itu, cara lain yang mungkin dapat diterapkan adalah dengan menggunakan drone (Gambar 3.) untuk menghasilkan citra udara, atau menggunakan data satelit.

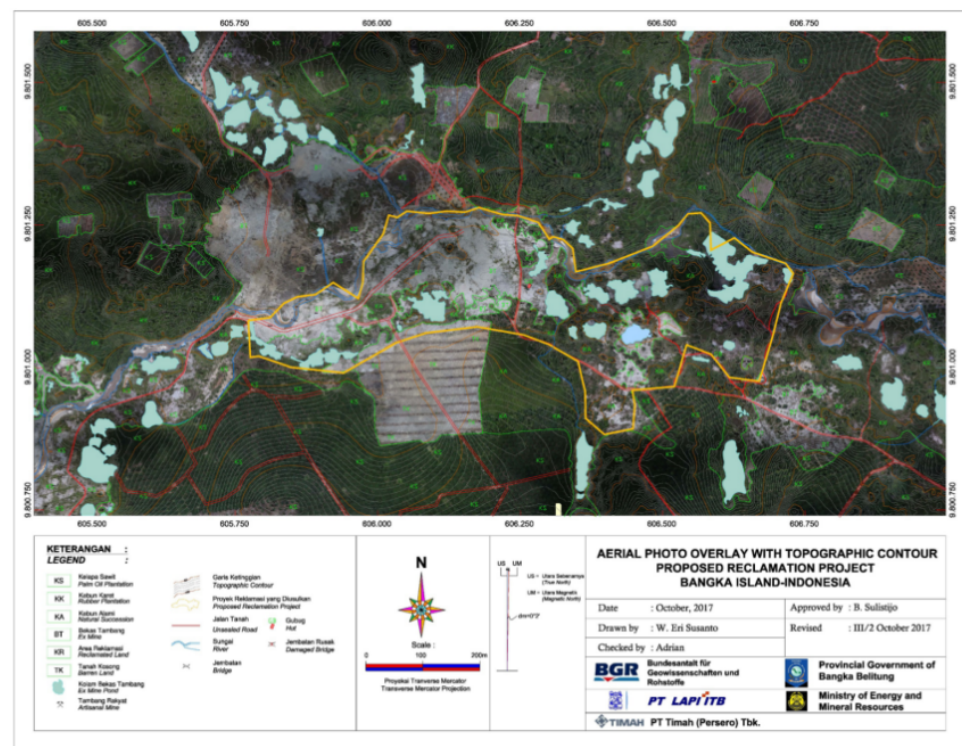

Gambar 23 Contoh Hasil Pemetaan Drone

Gambar yang dihasilkan kemudian harus dianalisis untuk memberikan informasi tentang tutupan lahan dan kondisi topografi daerah secara detail. Kemudian

- Tetapkan desain reklamasi umum dengan menggabungkan status lahan, RTRW, tutupan lahan, dan informasi topografi yang berasal dari peta atau gambar satelit / drone (atau model elevasi digital).

- Perjelas skala operasi "cut and fill" untuk membentuk permukaan lahan. Proses ini membutuhkan waktu yang cukup, sumber daya keuangan, dan evaluasi terperinci dari risiko erosi, mis. karena limpasan permukaan air. Manajemen risiko erosi diperlukan setelah permukaan lahan dibentuk.
- Setelah pelaksanaan "cut and fill" dilakukan untuk persiapan lahan, lakukan pemetaan tekstur tanah dan kadar air tanah. Sesuaikan rencana reklamasi dengan kondisi tanah aktual yang ditemukan di daerah tersebut.

- Konsultasi dengan pakar pertanian dan kehutanan serta masyarakat setempat mengenai jenis tanaman yang akan digunakan untuk reklamasi, berdasarkan peraturan dan target keberhasilan serta jenis tekstur tanah dan prosedur perbaikan yang direncanakan.

- Diskusikan dan sesuaikan tanaman yang dipilih untuk reklamasi dengan petani lokal, BUMDES dll. mengenai rekomendasi dan pengalaman mereka serta dalam konteks 
model bisnis umum masyarakat setempat. Pertimbangkan kondisi pasar lokal untuk model bisnis komunitas dan sesuaikan zona penanaman dan jadwal yang sesuai (mis., Kontrol jumlah produk panen untuk sampai di pasar selama periode tertentu).

- Sesuaikan desain rencana reklamasi dengan jenis tanaman atau tanaman yang akan dibudidayakan (pohon kehutanan, tanaman tahunan, tanaman tahunan, atau tanaman hortikultura?) Karena hal ini akan menentukan rencana detail persiapan lahan, kisi-kisi penanaman, kebutuhan bibit, juga sebagai dosis tanah merah, kompos, kapur, dan pupuk atau pupuk alternatif (misalnya, biochar, pupuk kandang dan kulit umbi atau residu organik lainnya) untuk perbaikan tanah.

- Pertimbangkan integrasi infrastruktur pendukung yang diperlukan (jalan inspeksi, drainase dan sistem irigasi, gudang, fasilitas pembibitan, pembuatan kompos di tempat).

\section{Pengelolaan Lubang Tambang berbentuk Kolong}

Kegiatan penambangan timah di masa lalu menghasilkan distribusi kolong yang tersebar di wilayah tersebut, dengan perbedaan yang signifikan dalam hal ukuran, kedalaman, volume air dan kualitas yang menentukan penggunaannya sebagai sumber air untuk kegiatan domestik, irigasi, budidaya ikan, dll. Untuk berbagai jenis penggunaan ini, kualitas air harus mematuhi peraturan yang berlaku.

Jika ada ketersediaan material lapisan penutup, alat berat, dll. Kolong berukuran kecil dan dangkal harus ditutup selama pengaturan permukaan tanah (landscaping) dengan cara ditimbun. Jika tidak, harus dilakukan pembentukan lereng dimana lereng kolong tidak lebih dari lereng alamiah material timbunan (the angle of repose); sudut lereng ini bervariasi sesuai dengan kadar air dan distribusi ukuran butir material.

Lubang tambang yang lebih besar dapat digunakan sebagai reservoir air yang terhubung ke sistem irigasi atau dimanfaatkan untuk memenuhi fungsi ekonomi seperti perikanan atau, dalam beberapa kasus menjadi tempat pariwisata. Kolong besar juga harus diintegrasikan dengan sistem drainase untuk digunakan sebagai air penyangga. Langkah-langkah keamanan yang tepat harus dipertimbangkan sebagaimana didefinisikan di bawah ini.

- Tutup kolong kecil dan dangkal ketika membentuk permukaan lahan dengan cara ditimbun. Untuk kolong kecil dan besar di mana penimbunan kembali tidak dimungkinkan, pertimbangkan untuk membentuk lereng ulang (resloping). Lakukan analisis kestabilan lereng untuk area yang berbahaya.

- Ketika digunakan sebagai reservoir air, tentukan ukuran dan kedalaman kolong yang lebih besar di area reklamasi untuk memperkirakan dimensi dan volume airnya. Gunakan peta topografi atau gambar drone untuk membantu. Pertimbangkan perubahan musiman curah hujan dan dampaknya terhadap ketinggian air kolong.

- Tentukan kualitas air kolong dengan mengacu pada Peraturan Pemerintah No. 82/2001 atau peraturan daerah yang berlaku.

- Untuk kolong permanen yang besar dan tidak ditutup selama pembentukan permukaan lahan: Saat melakukan revegetasi, tanam pohon kehutanan atau tanaman tahunan dengan jarak tanam dekat sepanjang tepi kolong sebagai pagar hidup atau hijau untuk meminimalkan risiko kecelakaan (orang jatuh ke dalam kolam), dan pasang papan tanda untuk keselamatan, kesehatan, dan kesadaran lingkungan di posisi strategis di sepanjang setiap kolong di area tersebut.

Diskusikan dengan organisasi masyarakat setempat tentang pengalaman mereka dalam memancing atau berternak ikan ataupun kegiatan wisata untuk memanfaatkan kolong dan memberikan nilai ekonomi.

\section{Pembentukan Permukaan Lahan dan Kontrol Erosi}

Wilayah kepulauan di area tropis mempunyai karakteristik cuaca dan kondisi hidrologi yang dinamis. Hujan deras atau kondisi yang sangat kering dengan suhu tinggi berlangsung sepanjang tahun. Oleh karena itu, area reklamasi harus dilindungi dari kekeringan atau tanah longsor, erosi tanah, dan air limpasan yang berlebihan yang dapat menghanyutkan kompos, kapur, pupuk, dan bahkan bibit tanaman yang baru ditanam. Khusus untuk area terbuka (kurang tutupan vegetasinya) yang belum ditanami dan memiliki lubang, saluran atau tumpukan lapisan batuan penutup tambang, perlu dilakukan upaya konservasi tanah dengan membuat terasering dan meratakan permukaan tanah untuk mendapatkan area yang stabil.

Pengaturan permukaan tanah dilakukan dengan teknik "cut and fill" dengan menggunakan alat berat, hal ini dapat menyebabkan pemadatan tanah. Meskipun kemungkinan pemadatan tanah yang terjadi di tanah berpasir jauh lebih rendah daripada ditanah dengan kandungan tanah liat tinggi, pemadatan tanah harus dihindari di mana saja di area reklamasi. 
- Mengatur permukaan tanah (landskap) dengan melakukan teknik "cut and fill" untuk menyiapkan lahan bertingkat dengan kemiringan $<5 \%$ dan perbedaan ketinggian $<1 \mathrm{~m}$ untuk mengurangi potensi erosi tanah. Kegiatan ini meliputi perataan tanah dan konstruksi jalan inspeksi, saluran drainase, dan konservasi tanah dan air.

- Bangun sistem drainase yang memadai untuk mencegah erosi atau banjir, mengelola limpasan air permukaan dan menghindari kondisi genangan air. Saat merencanakan sistem drainase, pertimbangkan topografi regional termasuk potensi aliran air dari daerah sekitarnya (Gambar 4).
- Melindungi fungsi sistem drainase dengan langkah-langkah yang memadai seperti perangkap sedimen (Gambar 5) (penghalang) atau melapisi selokan dengan semen untuk menghindari pembentukan erosi selokan. Pertimbangkan perlindungan infrastruktur seperti jalan akses saat merekayasa sistem drainase. Sistem drainase membutuhkan perawatan rutin.

- Lakukan metode lain (seperti penanaman tanaman penutup, dll.) Untuk mengurangi erosi tanah seminimal mungkin.

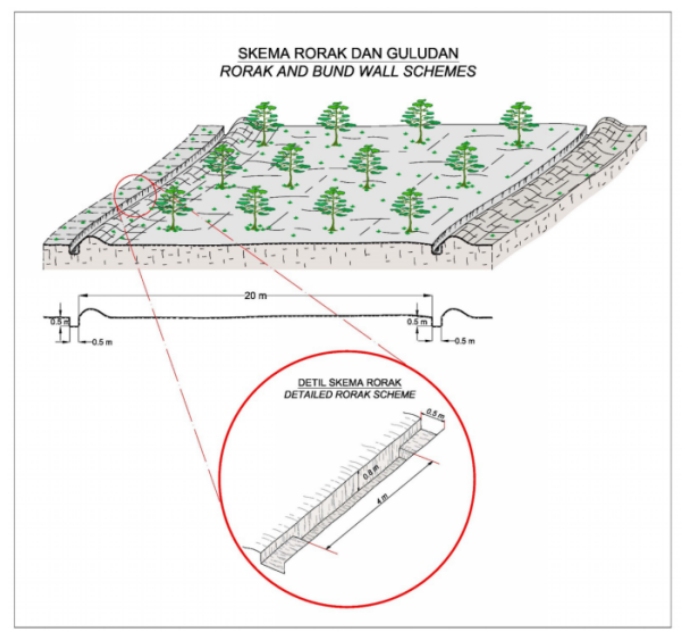

Gambar 4: Desain mengurangi erosi permukaan di area dengan aliran air menggunakan "rorak"

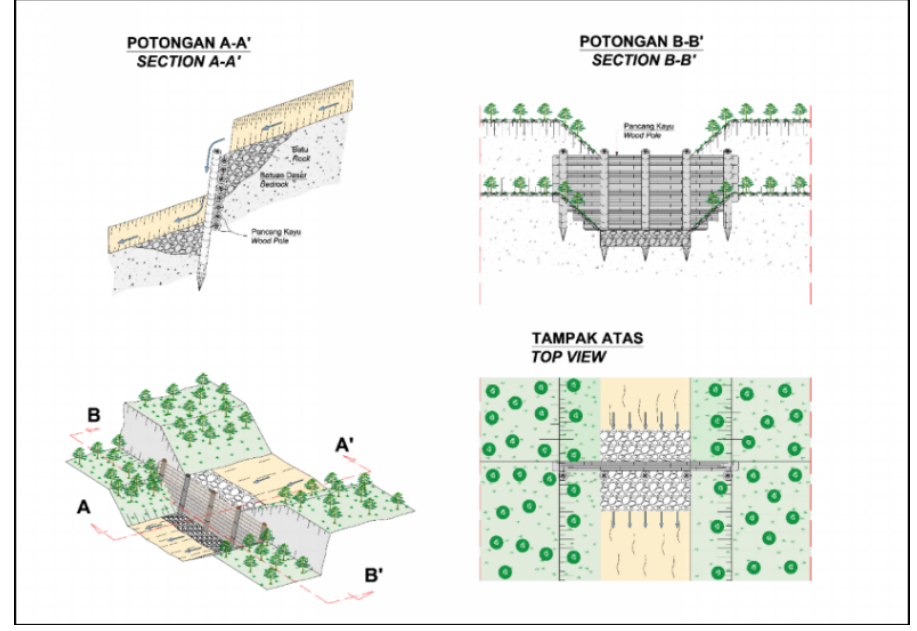

Gambar 5: Desain untuk kestabilan lereng curam di daerah dengan aliran air 


\section{Akses dan Pemeliharaan Kontruksi Jalan}

Untuk memfasilitasi implementasi, pemeliharaan, dan pemantauan kegiatan reklamasi maka jalan akses dan inspeksi harus dibangun.

- Bangun jaringan jalan inspeksi dengan dimensi yang memungkinkan untuk memfasilitasi pengangkutan alat, peralatan, tanah merah skala kecil, kompos, kapur, pupuk, tanaman, dan input lainnya.

- Jalan akses harus mampu menopang berat truk yang mungkin membawa material berat (10-20 ton). Jalan dapat dibangun menggunakan bahan beton yang lebih stabil atau desain tanah yang dipadatkan yang lebih murah. Akses truk mungkin lebih sulit selama musim hujan. Bergantung pada rencana reklamasi, akses truk mungkin perlu dilakukan baik pada musim kemarau maupun hujan.

- Desain konstruksi jalan harus mempertimbangkan fasilitas drainase yang memadai untuk melindungi dari erosi. Jalan dan fasilitas drainase terkait membutuhkan pemeliharaan rutin.

- Libatkan masyarakat setempat dalam pembangunan jalan, idealnya sebagai subkontraktor di tingkat organisasi (BUMDES atau Koperasi), jika tidak atas dasar perorangan.

\section{Kontrol Banjir dan Zona Penyangga}

Banjir adalah risiko yang signifikan selama musim hujan. Banjir dapat terjadi di lokasi reklamasi itu sendiri karena curah hujan yang tinggi dan naiknya permukaan air di sungai-sungai terdekat. Banjir juga memiliki dampak regional dan manajemen banjir harus mempertimbangkan daerah tangkapan air regional untuk meminimalkan potensi kerusakan di bagian hilir.

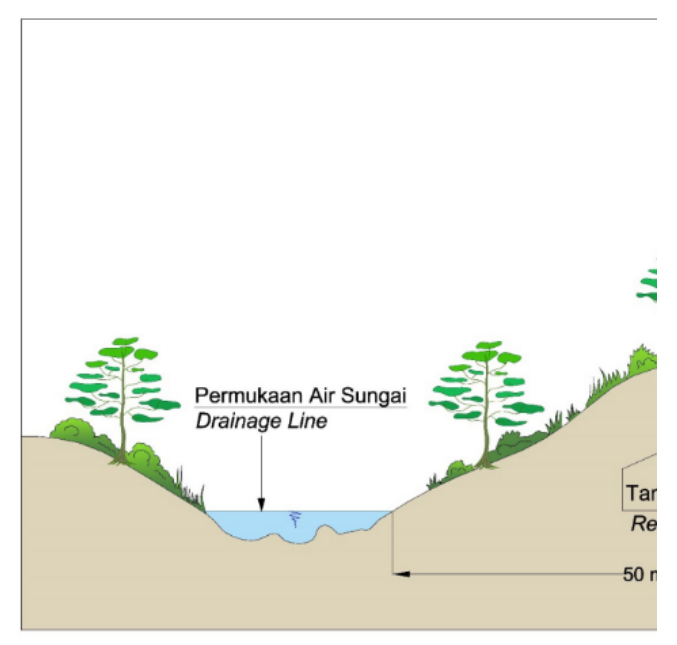

- Sungai mungkin mengandung sedikit air di musim kemarau tetapi aliran air menjadi tinggi selama musim hujan. Langkah-langkah pengendalian banjir harus didasarkan pada risiko banjir musim hujan dan memperhitugkan periode ulang banjir 10 tahun.

- Tanyakan di antara anggota masyarakat setempat tentang pengalaman mereka dengan peristiwa banjir di masa lalu: daerah mana yang memiliki risiko tinggi dan berapa frekuensinya? Pertimbangkan informasi ini untuk perencanaan tindakan pengendalian banjir.

- Pengendalian banjir mengacu pada pipa saluran pembuangan di bawah jalan akses atau infrastruktur penting lainnya untuk mengelola hujan lebat. Jika ada, integrasikan jaringan kolam tambang besar (kolong) sebagai tempat penampungan air ke dalam sistem drainase yang dapat menahan air dan mencegah banjir di daerah atau jalan tertentu.

- Risiko banjir pada area reklamasi yang berasal dari air sungai dapat dikelola melalui berbagai pendekatan. Pendekatan terbaik adalah membangun zona penyangga yang luas (dataran banjir) di sebelah sungai (Gambar 6). Zona penyangga ini harus ditanami dengan tanaman yang cocok untuk bertahan hidup dalam skenario banjir sementara (tanah tergenang air), seperti Eucalyptus atau Sengon. Zona penyangga memberikan perlindungan area dengan tanaman yang berharga di ketinggian lebih tinggi dari lokasi reklamasi. Hal ini akan memperlambat kecepatan aliran air sungai sehingga mengurangi risiko banjir di hilir.

Gambar 10: llustrasi penambangan dan reklamasi di dekat sungai dengan menggunakan zona penyangga.

- Tanggul dapat dibangun untuk melindungi daerah dengan tanaman berharga dari banjir yang berasal dari sungai. Tanggul-tanggul ini harus dibangun di belakang zona penyangga di mana tidak memiliki risiko erosi yang tinggi. Dalam kasus ini, dapat distabilkan dengan tanaman

- Membangun tanggul secara langsung di sebelah sungai sangat berisiko karena adanya risiko erosi yang tinggi, dalam ini harus dihindari dengan membangun zona penyangga. Jika ini tidak memungkinkan maka tanggul harus distabilkan. Ini dapat dilakukan dengan menggunakan batu-batu 
besar atau puing-puing (mis. dengan bronjong) di area erosi tinggi, dan tanaman (bambu, rumput) di daerah tanggul yang lebih terlindungi. Diperlukan evaluasi teknik sipil (hidraulik) untuk pola aliran air sungai untuk mengidentifikasi area dengan erosi tinggi; catatan bahwa area-area ini dapat berubah sepanjang waktu dan erosi juga dapat terjadi di dasar tanggul, di bawah langkah-langkah perlindungan air permukaan.

- Pengendalian banjir dapat juga merujuk pada perubahan dasar sungai atau morfologi untuk stabilisasi atau modifikasi aliran. Jika perusahaan pertambangan ingin melakukan evaluasi hidrolik untuk merencanakan intervensi ini, maka akan membutuhkan tenaga ahli teknik sipil untuk menghitung laju aliran sungai dll. Dampak daerah tangkapan dari setiap intervensi perlu dievaluasi dengan cermat untuk menghindari masalah di lokasi lain (hilir). Untuk perusahaan ya kecil mungkin tidak memiliki tenaga ahli internal yang diperlukan untuk evaluasi tersebut maka perlu mengontrak tenaga ahli eksternal.

\section{Air Bendungan dan Irigasi}

Diperlukan curah hujan yang melimpah untuk mendukung pertumbuhan awal tanaman reklamasi. Yang terakhir ini penting untuk menentukan awal periode tanam yang harus bertepatan dengan awal musim hujan; biasanya ini adalah periode dari Oktober hingga Januari, tetapi dapat bervariasi antar kabupaten per satu bulan, dan juga dapat bervariasi dari tahun ke tahun.

- Dapatkan dan evaluasi data curah hujan, mis., Curah hujan bulanan rata-rata dan jumlah hari hujan, selama periode 10 tahun terakhir.

- Bicaralah dengan petani setempat tentang pengalaman mereka dengan pola musim hujan.

Irigasi diperlukan selama musim hujan dan terutama pada musim kemarau. Air untuk keperluan irigasi dapat bersumber dari air hujan, reservoir air permukaan atau air tanah. Waduk air permukaan sering diwakili oleh kolam tambang (kolong); ini biasanya diisi ulang oleh air hujan dan karenanya tinggi muka air akan berkurang selama musim kemarau. Namun, tergantung pada topografi dan hidrologi daerah, kolong yang lebih besar juga dapat diisi ulang dari air tanah yang dapat mengisi ulang selama musim kemarau. Jika kebutuhan irigasi lokal tidak dapat dipenuhi dari air kolong, sumber daya air tanah dapat diakses dengan membangun sumur produksi kecil. Kualitas air dari semua waduk potensial harus diperiksa untuk memenuhi standar peraturan yang berlaku terkait dengan penanaman tanaman. Untuk merencanakan dan membangun infrastruktur irigasi, perlu mempertimbangkan data jenis tanaman, kebutuhan air tanaman (evapotranspirasi), curah hujan, dan sifat fisik tanah (kapasitas penyimpanan air ditentukan oleh tekstur, porositas, dan permeabilitas). Oleh karena itu, perencanaan sistem irigasi harus dibantu oleh ahli hidrologi dan ahli pertanian.

- Identifikasi satu atau lebih reservoir air yang sesuai. Mengevaluasi total volume reservoir air dan menghubungkannya dengan persyaratan irigasi tanaman reklamasi (evapotranspirasi) selama musim kemarau.

- Jika kolong digunakan sebagai reservoir untuk irigasi, pastikan kualitas airnya sesuai dan pertimbangkan fluktuasi musiman ketinggian air kolong. Ukur kedalaman kolong dan hitung volume total air. Mengevaluasi apakah kolong dapat bertindak sebagai reservoir dengan air yang cukup sepanjang musim kemarau. Perjelas jika kolong terhubung ke air tanah dan karenanya dapat diisi ulang secara terpisah dari curah hujan (memerlukan evaluasi hidrologi).

- Mengakses dan mendistribusikan air dari reservoir ini memerlukan pemasangan pompa yang terhubung ke menara buatan besi (biasanya 2-3 m dengan tangki penyimpanan air di bagian atas) untuk memasok air ke pipa irigasi.

- Bangun pipa irigasi dengan diameter (biasanya bahan PVC, 1 inci), panjang dan sistem distribusi (nozel penyiram) disesuaikan dengan kebutuhan evapotranspirasi instalasi reklamasi dengan asumsi penyiraman dilakukan dua kali per minggu.

- Perhatikan bahwa kebutuhan irigasi untuk tanaman mungkin lebih tinggi pada tahap awal reklamasi.

- Jika ketersediaan air lokal rendah, pertimbangkan untuk menggunakan tanaman reklamasi yang mampu bertahan dalam lingkungan air sedikit.

\section{HASIL DAN PEMBAHASAN}

Penerapan konsep reklamasi dan pasca tambang di daerah alluvial yang baik telah menunjukan hasil yang menjanjikan di lapangan.

Keberhasilan program reklamasi dan pascatambag yang berkelanjutan sangat tergantung dari persetujuan dari dinas terkait dalam reklamasi dan pasca tambang. Karena begitu mendapat persetujuan program reklamasi dan pasca tambang maka perusahaan harus memasukkan jaminan reklamasi di depan selama 5 
tahun untuk tambang dengan dengan ijin IUP OP atau cadangan lebih dari lima tahun dan harus menyelesaikan jamainan pasca tambang 2 tahun sebelum akhir IUP OP atau akhir cadangan.

Munculnya masalah reklamasi dan pasca tambang karena jaminan reklamasi dan pasca tambang mengacu pada design reklamasi dan pasca tambang yang disetujui, padahal pada banyak kasus design reklamasi dan pasca tambang yang baik sulit diterapkan dengan design dan biaya yang telah ditetapkan. Kondisi ini menciptakan "image bahwa" bagi masyarakat bahwa kegiatan reklamasi dan pasca tambang dilakukan sekedarnya saja. Kondisi ini diperparah lagi di beberapa tempat bekas tambang menjadi tujuan wisata dengan sedikit memberi keselamatan pada pengunjungnya dan tidak memberikan edukasi dampak dari pelaksaan reklmasi dan pascat tambang yang tidak tepat.

Air kondur 3 merupakan suatu percontohan reklmasi yang sudah didisain sejak awal dengan biaya yang cukup dan melibatkan masyarakat agar lokasi bekas tambang di dapat direklamasi dengan baik dan benar karena kita harus menyadarkan babwa kegiatan reklamasi dan pasca ambang merupakan kegiatan yang harus di desain dengan baik dan benar baik dari sisi manfaat dan pembiayaan agar tujuan reklamasi dan pasca tambag yang berkelanjutan dapat di capai dengan baik. Design reklamasi harus dibuat seiring dengan kemajuan dan harus dievaluasi dengan ketat apakah bisa dilaksanakan di lapangan atau tidak baik dari sisi teknis dan biaya yang masuk akal serta pengawasan dalam pelaksanaan.

\section{KESIMPULAN}

Pemetaan udara, hidrogeologi dan penilaian bahaya geologi di rencana lokasi reklamasi didesain untuk memenuhi persyaratan agar rencana reklamasi dapat berhasil. Strategi lain adalah untuk mempertahankan kesinambungan/keberlanjutan untuk menghindari gangguan baik penambang liar ataupun perambah hutan.

Kata kunci untuk mewujudkan reklamasi dan pasca tambang yang berkelanjutan adalah design yang baik dan biaya yang cukup dengan menerapkan keterlibatan masyarakat. Serta mampu mengantisipasi terjadinya pengkayaan bijih atau teknologi serta harga sehingga proses penambangan kembali di lahan reklamasi tidak terjadi.

\section{UCAPAN TERIMA KASIH}

Pada kesempatan ini, kami sampaikan terima kasih sebesar-besarnya kepada BGR, PT Timah dan ESDM yang telah memberikan dukungan fasilitas penelitian lapangan sampai penerapannya.

Catatan

Secara lengkap informasi rekklamasi dapat ditemukan:

1. Buku pegangan untuk praktek terbaik dalam reklamasi tambang darat timah alluvial di Indonesia. Pembelajaran dari Proyek Percontohan Reklamasi Air kondur 3, Provinsi Kepulauan BangkaBelitung

(https://www.bgr.bund.de/EN/Themen/Min_rohstof fe/Downloads/studie_reclamation_handbook_indo nesia_2019_bahasa.html

2. Handbook for best available practice in onshore alluvial tin mine reclamation in Indonesia: Learning Leasson from Air Kondur 3 Pilot Project Bangka Belitung Province

https://www.bgr.bund.de/EN/Themen/Min_rohstoff e/Downloads/studie_Reclamation_Handbook_Ind onesia_2019.html;jsessionid=2035A9818669C9D 282CBDE2AF8713E79.1_cid331?nn=1542388

\section{DAFTAR PUSTAKA}

,2014, "Peraturan Menteri ESDM No. 7 tahun 2014 tentang Pelaksanaan Reklamasi dan Pascatambang pada Kegiatan Usaha Pertambangan Mineral dan Batubara".

,(2018), "Keputusan Menteri Energi dan Sumber Daya Mineral Republik Indonesia No 1806 K/30/MEM/2018 tentang Pedoman Pelaksanaan Penyusunan, Evaluasi, Persetujuan Rencana Kerja dan Anggaran Biaya, serta Laporan Pada Kegiatan Usaha Pertambangan Minera dan Batubara".

,(2018), "Keputusan Menteri Energi dan Sumber Daya Mineral Republik Indonesia No 1827 K/30/MEM/2018 tentang Pedoman Pelaksanaan Kaidah Teknik Pertambangan yang Baik".

-,(2020), UU No 3/2020 "tentang Perubahan Atas Undang Undang No 4/2009 tentang Pertambangan Mineral dan Batubara"

Brouwer C, Heibloem M. 1986: Irrigation Water Management: Irrigation Water Needs. Training Manual No. 3. FAO.

Lubis, I. Azwardi. 2017: Teknik Penambangan Timah Aluvial, Humas PT Timah (Persero), Tbk

The Asia Foundation, 2016: Frugal Rehabilitation Methodology - Field Handbook. Tersedia online di https://asiafoundation.org/publication/frugalrehabilitation-methodology/ 